\title{
Antecedents To Customer Satisfaction: The Case of Supermarket Shoppers
}

\author{
Ma. Elena C. Estebal ${ }^{1 *}$ \\ ${ }^{1}$ Faculty of College of Business Education, Technological Institute of the Philippines
}

\begin{abstract}
A B S T R A C T
This study aimed to determine the level of satisfaction of the supermarket customers using the service quality (SERVQUAL) framework. It utilized a researcher-made questionnaire patterned from the original SERVQUAL questionnaire that was rephrased to fit the context of the focus of this study. The questionnaire is divided into 2 parts: the first part dealt with the demographic profile of the respondents and the second part dealt with level of respondents' agreement on the constructs of SERVQUAL which are generalized into five categories, tangibility, reliability, responsiveness, assurance and empathy. The dimensions of SERVQUAL are considered to be the determining factors for customer satisfaction. Based on the results obtained, it is evident that gap exist between expectations and actual service perception on the service quality of the supermarkets. The highest expectations were identified on reliability and empathy constructs while the lowest expectations were identified on responsiveness, assurance and tangibility constructs. For perception however, the highest were for tangibility and responsiveness construct while the lowest were identified in empathy, assurance and reliability constructs.
\end{abstract}

\section{ART I CLE INF O}

\section{Keywords:}

Service Quality,

Supermarkets,

Customer Satisfaction,

Perceptions,

Expectations.

*Corresponding Author E-mail: elenaestebal@gmail.com

Copyright (C) 2018Authors. This is an open access article distributed under the Creative Commons Attribution License, which permits unrestricted use, distribution, and reproduction in any medium, provided the original work is properly cited.

\section{INTRODUCTION}

The retail industry in the Philippines is poised for expansion and is expected to account for more than a fifth of the country's total economic output with the constant increase in the consumer spending of Filipinos. The president of Philippine Retailers Association (PRA), Lorenzo Formoso was quoted to have said that the retail sector is anticipating a $5 \%$ increase in its share of the gross domestic product (GDP) of the country from 18 percent in 2015 to at least 23 percent in 2016 (Mercurio, 2016). This expansion is due to the improved purchasing power of the Filipino consumer with an increase in the 
number of dual-income families. Since most families have both of the couple working, they demand a one-stop shopping offered by supermarkets. The uncharacteristically fast changing retail environments coupled with intensified competition among the players in the retail industry necessitates retailers to continuously implement marketing strategies in order to establish customer satisfaction. Supermarkets nowadays fulfill the very dynamic needs and demands of busy households.

A supermarket is a large, departmentalized retail store that is primarily engaged in selling food items (Marshall \& Nielson, 2001). The rapidly changing business environment coupled by more demanding supermarket customers and influx of competition makes it extremely hard for retailers to provide customer satisfaction. Gone are the days that most households would rely their household shopping needs on small groceries (sari-sari stores) situated a few blocks away from home. Retail supermarkets trade in a highly competitive industry, competitors are situated within a striking distance with each other with various assortments of product offerings both local and imported. Supermarket managers are well aware of the fact that if they will not able to provide what the customers are looking for customers can easily find another store that does (Codrington, 2002). It is extremely vital for supermarket retailers that wishes to establish customer relationship management (CRM) to identify the aspects of their operation that can enhance customer satisfaction. In order to properly identify the optimal retail strategies, it is vital to have a thorough understanding of the determinants of customer satisfaction. This is especially true in the case of retail industry specific to which the supermarkets. In this industry competition becomes intense each day, it is very important for the supermarket managers to identify the needs and wants of the customers and find a way to meet the identified needs and wants in order to satisfy them.

\section{LITERATURE REVIEW}

Customer satisfaction is a well-researched topic especially in the field of marketing. It is considered as one among the two most important factors to consider in developing retail strategies in supermarkets (Noyan \& Simsek, 2011). Customer satisfaction is a gratifying level of fulfilment that is related to consumption (Bloemer \& Schroder, 2002). It is a result of the customers' assessment after purchase of the overall service experience during the store visit. Customer satisfaction is an effective reaction wherein during service encounter the needs, desires, and expectations of the customers have been met (Menon \& Dube, 2000) and (Lovelock, 2001). Satisfaction inasmuch as profit is also a desired target for business, this is especially true because a satisfied customer is likely to repeat the purchase and to exert effort in spreading positive comments and opinions about their in-store experience to other customers.

Service quality for the longest time has been considered as a foundation of marketing strategy for companies due to intense competition and environmental factors. (Asubonteng, McCleary, \& Swan, 1996). Focusing on improving service quality is a vital strategy to gain customer satisfaction and to remain competitive in retail industry. Since supermarkets offer practically the same products, the in-store services provided by the supermarket staff makes a world of difference for the customers. If these in-store services meet their expectations or if they were able to have a pleasant shopping experience, it is expected that the customers will keep on coming in the store for more of their shopping needs.

This study made use of the service quality (SERVQUAL) framework in determining the level of satisfaction of the supermarket customers of the eight leading supermarkets in the Philippines. The SERVQUAL framework of measuring the scale of quality in service provision was developed by in 1985 and since then it has gained popularization among service businesses. It is a multi-item scale designed to identify consumer expectations and perceptions of a service considering the five dimensions that are believed to depict service quality. When it was first introduced, SERVQUAL model originally was composed of ten dimensions; 
tangibles, reliability, responsiveness, credibility, communication, competence, courtesy, security, understanding the customer, and access (Parasuraman, Zeithaml, \& Berry, 1985) however, these dimensions were summarized into five due to arguments that some dimensions are mere repetition of the others. The five dimensions that were maintained include tangibles which pertains to equipment, arrangement of physical facilities, personnel and communication materials ; reliability means capacity to perform the promised service accurately; assurance refers to the courtesy of staff and their capability to convey confidence and trust to the customers; responsiveness on the other hand pertains to willingness to help or provide assistance to customers and deliver prompt service; and empathy refers to the capacity of the firm to provide individualized attention customers (Arlen, 2008).

Customer satisfaction is a well-researched topic in the field of marketing because a very satisfied customer is more likely to repeat the purchase and is expected to spread through word of mouth the experience to friends, families or acquaintance. It pertains to the feeling an individual experiences when an offering exceeds his expectations (University of Minnesota, 2017), it pertains to the assessment of the perceived difference between actual performance and expectations of the product (Tse \&Wilton, 1988). Customer satisfaction pertains to the assessment process a customer conducts in the ongoing performance of a product or a service provider (Gustafsson, Johnson, \& and Roos, 2005), it is the customers' reaction to state of satisfaction (Kim, Park, \& Jeong, 2004), it enables customer to build long term profitable relationship with the brand (Hanif, Hafeez, \& Riaz, 2010). Noyan and Simsek (2011) investigated the effects of customer relationship proneness, store image, positive affect on customer satisfaction through structural equation modeling. The results of the study revealed a positive effect on the variables to customer relation. Further the study revealed that developing effective retail strategies are important in customer relationship management. The presence of demanding customers coupled with intensified competition in the industry necessitates well-planned retail strategies that can enhance customer satisfaction.

This study used service quality indicators i.e. tangibility, reliability, empathy, responsiveness and assurance to evaluate the customer perceptions against their expectations after service experiences in the respective supermarkets. The same dimensions were used to measure service quality and customer satisfaction because these two are related (Parasuraman, Zeithaml, \& Berry, 1988) and service quality is an antecedent to customer satisfaction (Negi, 2009). Customer satisfaction is linked with fruitful customer behavior from the perspective of the firm. Literature suggest association between service quality and satisfaction (Fornel, 1992) (Singh \& Thakur, 2012) (Kumar, Manjunath, \& Thimmaiah, 2012).

The SERVQUAL model is widely recommended by literature in the assessment of expectations and perceptions of service quality provided by businesses to their customers. In this study, both expectations and perceptions were measured using a 5-point scale to rate the respondent's level of agreement or disagreement (1-strongly disagree and 5-strongly agree). The higher the number, the higher the level of respondents' perceptions or expectations. Perceptions refers to the actual service received by the respondents in the respective supermarket while expectations refer to past experiences, word of mouth recommendations, and information about the supermarket. Service quality score is the difference between actual service perception and expectation (P-E). The service quality score measures the gap which refers to the degree to which respondents' expectations exceed perceptions. Gap 5 pertains to the discrepancy between customer expectations and their perception of the actual service delivered. A positive P-E score means favorable service quality experienced by the customers from the supermarket they have visited. The higher the positive P-E scores is equivalent to a higher level of service quality provided by the supermarket staff which brings about a higher level of customer satisfaction. 


\section{RESEARCH METHOD}

This study aimed to determine the level of satisfaction of the supermarket customers of the top eight supermarkets in the Metro Manila Philippines. In order to collect the required data, a questionnaire was developed using the SERVQUAL framework. The questionnaire includes a total of twenty-two (22) items from 2 perspectives: (1) expected, desired supermarket service performance and (2) perceived, actual supermarket service performance. The measurement items for each construct were adapted from existing literature using a 5-point Likert scale. 22 items were used in measuring the 5 SERVQUAL dimensions distributed as follow: tangibility 4 items, reliability 5 items, responsiveness 4 items, assurance 4 items and empathy 5 items. A total of 50 shoppers per supermarket were considered as respondents of the study. The respondents were chosen by the researcher using convenience and quota sampling technique. The questionnaires were distributed within the NCR for the months of May and June 2017. Administration of the questionnaires was done during the lax hours (between 10:00 AM - 3:00PM) to ensure that shoppers are not in a hurry. The accomplished questionnaires were collected by the researcher from the participants before they leave the supermarket premises. Data collected was processed using SPSS version 19.1. Frequency, percentage and mean were used for the description of the profile of respondents and their level of agreement on the 5 SERVQUAL dimensions.

\section{RESULTS AND DISCUSSION}

Among 400 respondents, 288 or 72 percent were female 112 or 28 percent were male. Majority of the respondents belong to the age range 41-45 years old with 72 or 18 percent, followed by 36-40 years old with 65 or 16.25 percent, while 46-50 years old got 56 or 14 percent, 26-30 years old with 52 or 13 percent, $21-25$ with 48 or 12 percent and 31-35 with 42 or 10.5 percent. The lower number of respondents belong to age range 56-60 with 30 or 7.5 percent, 51-55 with 29 or 7.25 percent and 61 and above with 6 or 1.5 percent. Employment as source of income of the respondents was more prominent than those who are self-employed which was represented by 318 or 79.5 percent and 82 or 20.5 percent, respectively. In terms of civil status of the respondents, majority are married with 205 or 51.25 percent followed by single with 159 or 39.75 percent, separated with 26 or 6.5 percent and widow/widower with 10 or 2.4 percent. There were more respondents with 3-4 household members represented by 252 or 63 percent and 1-2 household members represented by 90 or 22.5 percent. There were small numbers of respondents with 5-6 family members represented by 29 or 7.25 percent, 7 and more family members represented by 17 or 4.25 percent and no household member with 12 or 3 percent. Respondents divulged that majority of them went to supermarket as necessary with 144 or 36 percent, once a week with 102 or 25.5 percent. Only few who shopped every fifteen days to be specific 98 or 24.5 percent and once a month with 50 or 12.5 percent. There were 6 or 1.5 percent of the respondents whose frequency of shopping visits in the supermarket are other than those identified.

Table 1. Summary of Means of Customers' Expectations, Perceptions and Gap Scores on Tangibility

\begin{tabular}{|l|c|c|c|}
\hline Tangibility & Perceptions & Expectations & Gap Score \\
\hline Tangibility 1 & 4.22 & 3.71 & 0.51 \\
\hline Tangibility 2 & 4.28 & 4.14 & 0.14 \\
\hline Tangibility 3 & 3.98 & 4.30 & -0.32 \\
\hline Tangibility 4 & 4.33 & 4.16 & 0.17 \\
\hline \multicolumn{2}{|c|}{ Average Tangibility SERVQUAL Score } & 0.125 \\
\hline
\end{tabular}

The respondents divulged that in terms of their perceptions on tangibility as a SERVQUAL dimension, they strongly agree on supermarkets having an up-to-date point of sale (POS) terminal that provides fast service and multiple payment options, supermarket being clean and the goods are neatly arranged in the shelves and the supermarket having facilities that are consistent with other supermarkets while they agree on the supermarket staff must have clean and presentable appearance. On the other hand, when expectations were considered, respondents revealed that they strongly agree that the supermarket staff must 
have clean and presentable appearance and they agree on the three other dimensions. Average gap score for tangibility as a service quality dimension is 0.125 .

Table 2. Summary of Means of Customers' Expectations, Perceptions and Gap Scores on Reliability

\begin{tabular}{|l|c|c|c|}
\hline Reliability & Perceptions & Expectations & Gap Score \\
\hline Reliability 1 & 3.93 & 4.02 & -0.09 \\
\hline Reliability 2 & 3.92 & 4.35 & -0.43 \\
\hline Reliability 3 & 3.81 & 4.35 & -0.54 \\
\hline Reliability 4 & 3.78 & 4.33 & -0.55 \\
\hline Reliability 5 & 4.26 & 3.73 & 0.53 \\
\hline \multicolumn{2}{|c|}{ Average Reliability SERVQUAL Score } & -0.216 \\
\hline
\end{tabular}

Results revealed that considering reliability as a construct of SERVQUAL, the items with highest expectation scores were providing assistance in cases of returns of purchased items and other problems, staff must be ready to assist customers with heavy load, services must be delivered at times promised, and supermarket must provide accurate records of transaction. The item which rated the highest for actual service perceived was providing accurate records of transaction. Average score for reliability as a dimension for service quality is -0.216 . Further results revealed that in terms of reliability respondents have higher expectation than the service they actually received or experienced during their visit to the supermarket.

Table 3. Summary of Means of Customers' Expectations, Perceptions and Gap Scores on Responsiveness

\begin{tabular}{|c|c|c|c|}
\hline Responsiveness & Perceptions & Expectations & Gap Score \\
\hline Responsiveness 1 & 4.25 & 3.83 & 0.42 \\
\hline Responsiveness 2 & 4.38 & 4.23 & 0.15 \\
\hline Responsiveness 3 & 4.27 & 4.21 & 0.06 \\
\hline Responsiveness 4 & 4.14 & 3.83 & 0.31 \\
\hline \multicolumn{2}{|c|}{ Average Tangibility SERVQUAL Score } & 0.235 \\
\hline
\end{tabular}

As shown on Table 3, the highest expectation scores were supermarket staff must provide prompt service to the customers and must be willing to assist and extend help to the customers while for perception, the highest scores were identified on ability to provide prompt services to the customers, staff willing to assist and extend help to the customers and staff informing the customers as to when the service will occur. The average responsiveness SERVQUAL score is 0.235 . It is very evident that the respondents' actual service perceived exceeds the initial expectation on factors concerning the responsiveness of the supermarket staff in the needs and demands of the shoppers.

Table 4. Summary of Means of Customers' Expectations, Perceptions and Gap Scores on Assurance Construct

\begin{tabular}{|l|c|c|c|}
\hline Assurance & Perceptions & Expectations & Gap Score \\
\hline Assurance 1 & 3.83 & 4.23 & -0.4 \\
\hline Assurance 2 & 4.29 & 3.84 & 0.45 \\
\hline Assurance 3 & 4.28 & 3.99 & 0.29 \\
\hline Assurance 4 & 3.82 & 4.25 & -0.43 \\
\hline \multicolumn{2}{|c|}{ Average Assurance SERVQUAL Score } & -0.023 \\
\hline
\end{tabular}

Table 4 shows the level of agreement of the respondents on assurance as a SERVQUAL dimension. The highest score for expectation were noted for behaviors of supermarket staff instill confidence in customers and supermarket must provide employee recognition or commendation as a support to do their job well. On the other hand, the highest scores for actual service perceived were identified on customers of supermarket feel safe and secure while shopping and supermarket staff are courteous with customers. It is evident that actual service perceived exceeds expectations on assurance 2 and 3 which accounts for customers feeling safe and secure while shopping and staff being courteous with customers.

Table 5. Summary of Means of Customers' Expectations, Perceptions and Gap Scores on Empathy Construct

\begin{tabular}{|l|c|c|c|}
\hline Empathy & Perceptions & Expectations & Gap Score \\
\hline Empathy 1 & 4.03 & 4.24 & -0.21 \\
\hline Empathy 2 & 3.98 & 4.28 & -0.3 \\
\hline Empathy 3 & 4.08 & 4.29 & -0.21 \\
\hline Empathy 4 & 3.97 & 4.20 & -0.23 \\
\hline Empathy 5 & 4.35 & 4.04 & 0.31 \\
\hline \multicolumn{2}{|c|}{ Average Empathy SERVQUAL Score } & -0.128 \\
\hline
\end{tabular}


Results revealed that in terms of the level of agreement of the respondents on empathy as a construct of SERVQUAL, the highest expectation scores were generated on supermarket in general must be able to provide individualized attention to each customer, staff must provide individualized attention to each customer and staff must understand the needs of customers. The highest score for actual service perceived has been accounted only to one empathy factor which is the ability of supermarket operating on convenient hours. It is very evident that empathy as a construct for SERVQUAL, the respondents have higher expectations than the actual service perceived which is why in almost all factors a negative gap score was recorded. It must be noted though that the time of operation of supermarkets which is typically from 9:00 am to 10:00 pm is viewed by the respondents as vital in the service performance of supermarkets.

Table 6. SERVQUAL Importance Weights

\begin{tabular}{|l|c|}
\hline \multicolumn{1}{|c|}{ SERVQUAL Dimensions } & Rank \\
\hline $\begin{array}{l}\text { 1. The appearance of the physical facilities, } \\
\text { equipment, personnel, and communication } \\
\text { materials of the supermarket }\end{array}$ & 2 \\
\hline $\begin{array}{l}\text { 2. Ability to perform the promised service } \\
\text { dependably and accurately }\end{array}$ & 4 \\
\hline $\begin{array}{l}\text { 3. Willingness to help customers and } \\
\text { provide prompt service }\end{array}$ & 1 \\
\hline $\begin{array}{l}\text { 4. The knowledge and courtesy of the } \\
\text { supermarket's staff and their ability to } \\
\text { convey trust and confidence }\end{array}$ & 3 \\
\hline $\begin{array}{l}\text { 5. The individualized attention the } \\
\text { supermarket provides its customers }\end{array}$ & 5 \\
\hline
\end{tabular}

The respondents were asked to indicate importance weights on the identified SERVQUAL dimensions. The results revealed that the highest score was given to responsiveness construct specifically referring to willingness to assist customers and provide prompt service, the next highest score was given to tangibility construct which pertains to the appearance of the physical facilities, equipment, personnel, and communication materials. The third rank was awarded to assurance construct specifically pertaining to knowledge and courtesy of staff as well as their ability to convey trust and confidence. The fourth rank on the other hand was awarded to the reliability construct or the ability of the supermarket staff to dependably and accurately perform the promised service. The last rank was given to empathy construct specifically pertaining to the ability of the supermarket staff to provide individual attention to the supermarket shoppers.

Table 7. SERVQUAL Weighted Scores

\begin{tabular}{|l|c|c|c|}
\hline \multicolumn{1}{|c|}{$\begin{array}{c}\text { SERVQUAL } \\
\text { Dimensions }\end{array}$} & $\begin{array}{c}\text { Gap } \\
\text { Scores }\end{array}$ & $\begin{array}{c}\text { Importance } \\
\text { Weight }\end{array}$ & $\begin{array}{c}\text { Weighted } \\
\text { Score }\end{array}$ \\
\hline Average Tangibility & 0.125 & 25 & 3.13 \\
\hline Average Reliability & -0.216 & 18 & -3.89 \\
\hline Average Responsiveness & 0.235 & 28 & 6.58 \\
\hline Average Assurance & -0.023 & 19 & -0.44 \\
\hline Average Empathy & -0.128 & 10 & -1.28 \\
\hline \multicolumn{2}{|c|}{ Average Assurance SERVQUAL Score } & 4.1 \\
\hline
\end{tabular}

Table 7 summarizes the SERVQUAL weighted scores. Responsiveness as a construct of SERVQUAL got the highest positive weighted score of 6.58 which implies that the expectation has been exceeded by actual service perceived on aspects concerning willingness to help customers and provide prompt service. Tangibility on the other hand generated a weighted score of 3.13 which implies that on aspect concerning appearance of the physical facilities, equipment, personnel, and communication materials actual service perceived exceeded the expectation of the supermarket customers. Although the overall weighted SERVQUAL score is positive because actual service perceived exceeds the customers expectation and importance weight assigned by the respondents on tangibility and responsiveness, it must be noted that 3 constructs generated negative gap score. Reliability, empathy and assurance generated a negative gap score with a rating of $-3.89,-1.28$ and -0.44 respectively. Reliability which generally refers to supermarket's ability to perform the services promised accurately generated the highest negative gap score of -0.216 and weighted average of -3.89 , empathy which generally refers to individual attention the supermarket provides its customers generated 
the second highest negative gap score of -0.128 with weighted average of -1.28 and assurance which deals with the courtesy of the staff of the supermarket and their ability to convey trust and confidence generated negative gap score of -0.023 with a weighted average of -0.44 .

\section{CONCLUSION}

Based on the results obtained, it is evident that gap exist between expectations and actual service perception on the service quality of the supermarkets. It is common for consumers' expectation of service offerings to exceed the actual service perceived which in turn signifies a need for improvement (Parasuraman, Zeithaml, \& Berry, 1988). The highest expectations were identified on reliability and empathy constructs while the lowest expectations were identified on responsiveness, assurance and tangibility construct. For perception however, the highest were for tangibility and responsiveness construct while the lowest were identified in empathy, assurance and reliability constructs.

The results of the research showed for tangibility and responsiveness constructs; the actual services perceived by the respondents during their supermarket visit exceeded their expectations. Further results revealed that the supermarket customers are satisfied with the visual appeal and the updated physical facilities and equipment of the supermarket, ability of the supermarket staff to provide prompt service to requests as well as willingness of the staff to provide assistance. However, for the reliability, assurance and empathy constructs, their expectations with the service quality of the supermarkets were not met. It is therefore recommended to formulate marketing strategies specifically adhering to service quality improvement that is focused on reliability, assurance and empathy constructs to improve the level of satisfaction of the supermarket customers. In order to address the identified gaps on the three constructs, it is recommended for the supermarket managers to provide customer relationship management (CRM) training for the supermarket staff to improve the level of satisfaction of their customers.
For reliability, it is important for the staff to learn how to respond on customers inquiries and complaints, they must be able to handle or facilitate returns of purchased items, they must also be ready to provide assistance for customers who are carrying heavy grocery baskets. Reliability got the second highest expectation score while it got the lowest score services perceived. This only show the level of dissatisfaction of the customers on the reliability dimension of the services provided by the supermarkets. Adhering to assurance, it is recommended for the supermarket managers to install CCTV cameras and other security measures so that the customer will feel safe while doing their shopping. It is also vital the supermarket managers to provide employee recognition/commendation as a reward for staff who are excellently doing their job. This can be done by means of requesting the customers to evaluate the performance of the staff they transacted with. They can also be asked to provide comments and suggestions on how to better improve the services offered by the supermarket.

By doing this, the customers will feel empowered which increases the likelihood of increasing their level of satisfaction. Empathy got the highest expectation rating which implies that the customers are really keen on the treatment they receive from supermarket staff. It is vital for the supermarket managers to develop marketing strategies that will make the customer feel that they are being given individual attention. A carefully crafted marketing strategies that is patterned from well identified customers' needs and wants will help improve service quality and increase the level of satisfaction because this would show that the supermarket staff have the customers' best interest in mind. It is recommended to expand future research on the facets of service quality in other industries since this study is only limited to the top eight supermarkets in the Philippines. 


\section{RE F EREN CES}

Arlen, C. (2008, October 24). Service Performance Inc. Retrieved from Service Performance Website: http://www.serviceperformance.com/the-5-service-dimensions-all-customers-care-about/

Asubonteng, P., McCleary, K., \& Swan, J. (1996). SERVQUAL Revisited: A Critical Review of Service Quality,. The Journal of Services Marketing, 62-81.

Bloemer, J., \& Schroder, G. (2002). Store Satisfaction and Store Loyalty Explained by Customer and Store Related Factors. Journal of Consumer Satisfaction, Dissatisfaction and Complaining Behavior, 68-80.

Cambridge University Press. (2017, June 10). Retrieved from Cambridge University Press: https://dictionary.cambridge.org/us/dictionary/english/supermarket

Codrington, G. (2002). Welcome to the Future World. Future Business: Marketing, Media, and Business in S.A., $38-40$.

Cook, C., \& Thompson, B. (2000). Reliability and Validity of SERVQUAL Scores Used to Evaluate Perceptions of Library Service Quality. The Journal of Academic Librarianship, 248-258.

Didactic Encyclopedia. (2017, November 5). Retrieved from Didactic Encyclopedia: https://edukalife.blogspot.com/2013/01/definition-of-supermarket.html

Encyclopaedia Britannica. (2017, November 5). Retrieved from Encyclopaedia Britannica: https://www.britannica.com/topic/supermarket

Fornel, C. (1992). A national customer satisfaction barometer: the Swedish experience. Journal of Marketing, $1-2$.

Gustafsson, A., Johnson, M., \& and Roos, I. (2005). The Effects of Customer Satisfaction, Relationship COmmintment Dimensions, and Triggers on Customer Retention. Journal of Marketing, 210-218.

Hanif, M., Hafeez, S., \& Riaz, A. (2010). Factors Affecting Customer Satisfaction. International Research Journal of Finance and Economics, 60.

Kim, M. K., Park, M. C., \& Jeong, D. H. (2004). "The Effects of Customer Satisfaction and Switching Barrier on Customer Loyalty in Korean Mobile Telecommunication Services. Electronics and Telecommunications Research Institute, School of Business, Information and Communications University, 305-348.

Kumar , A., Manjunath , S. J., \& Thimmaiah, A. (2012). Service Quality in Super Markets: A Study of Consumers Satisfaction in Apparel Retailing. IOSRJournal of Business and Management, 49-53.

Kuo, Y. F. (2003). A study on Service Quality of Virtual Community Websites . Total Quality Management \& Business Excellence, 461-473.

Lovelock, C. (2001). A Retrospective commentary on the article "New Tools for Achieving Service Quality". The Cornell Hotel and Restaurant Administration Quarterly, 42, 39-46. doi:https://doi.org/10.1016/S0010-8804(01)80043-4

Marshall, G., \& Nielson, A. C. (2001). South Africa's Shopping: Questions Answered. Progressive Retailing, 41-43.

Menon, K., \& Dube, L. (2000). Ensuring Greater Satisfaction by Engineering Salesperson Response to Customer Emotions. Journal of Retailing, 76 (3), 76 (3), 285-307.doi:https://doi.org/10.1016/ S0022-4359(00)00034-8

Mercurio, R. (2016, June 25). Retail SPending Seen to Hike Share in GDP. The Philippine Star. Retrieved from The Philippine Star.

Negi, R. (2009). Determining Customer Satisfaction Through Perceived Service Quality: A Study of Ethiopian Mobile Users. International Journal of Mobile Marketing, 31-38.

Noyan, F., \& Simsek, G. G. (2011). Structural Determinants Of Customer Satisfaction In Loyalty Models: Turkish Retail Supermarkets. Procedia Social and Behavioral Sciences, 2134-2138.

Parasuraman, A., Zeithaml, V. A., \& Berry, L. L. (1985). A Conceptual Model of Service Quality and its Implications for Future Research. Journal of Marketing, 41-50. 
Parasuraman, A., Zeithaml, V. A., \& Berry, L. L. (1988). SERVQUAL: A Multiple-Item Scale for Measuring Consumer Perceptions of Service Quality. Journal of Retailing, 12-40.

Parusaman, A., Ziethhaml, V., \& Berry, L. (1990). Delivering Quality Service: Balancing Customer Perceptiosn and Expectations. New York: Free Press.

Qadri, U. A. (2015). Measuring Serivce Quality Expectation and Perception Using SERVQUAL: A Gap Analysis. Business and Economics Journal, 1-6.

Singh, A. P., \& Thakur, S. (2012). Impact of Service Quality on Customer Satisfaction and Loylaty: In the Context of Retail Outlets in DB City Shopping Mall Bhopal. International Journal of Management Research and Review, 334-344.

Tse, D. K., \& Wilton, P. C. (1988). Models of Consumer Satisfaction Formation: An Extension. Journal of Marketing Research, 204-12.

University of Minnesota. (2017, November 5). Retrieved from University of Minnesota Libraries: https://www.lib.umn.edu/publishing/works/textbooks 